\title{
Trends and Prospects of Social Security Program in Nepal
}

Ghanashyam Niroula

\begin{abstract}
The objective of the paper is to examine the current status, trend and growth of the social security program over the years in Nepal. The secondary data for four years has been used and data were obtained from the websites of the Ministry of Federal Affairs and Local Development. There are ten different categories of beneficiaries viz. senior citizens, senior Dalits, widow, single women, endangered indigenous nationalities, Dalit children, Karnali zone children, severe affected disable, fully disable, Karnali zone senior citizens who are receiving allowances as social security benefits.

The study concludes that during the study period, all allowances except treatment for senior citizens (70 years and above) increased by 100 percent. The rate of allowances was lowest for children (Karnali and Dalit) and highest rate for fully disabled, Endangered Indigenous/ Nationalities. It is seen that the government is more concerned towards the health of the senior citizens 70 years and above. The number of beneficiaries viz. senior citizens all (Dalits, Karnali and others), disable (Fully and severly affected), Endangered ethnic group is in increasing trend while Single/widow and Children (Dalit and Karnali) have been found in decreasing trend. Out of five clusters, the number of elder citizens is highest followed by single widow and children of Dalit and Karnali zone. Disable (Fully and severly affected) and Endangered ethnic group are only 4 percent of total beneficiaries in 2015/16. The growth of the total beneficiaries is less than 1 percent during three year period but number of disabled increased by 95\% while widow/single women decreased by 10 percent in three years. Throughout the last three fiscal years, the largest number of beneficiaries were senior citizens followed by Single women/widow and children.
\end{abstract}

Keywords: Social Security, Vital Events, Old Citizens, Indigenous Group, Social Security Allowlances

1 Associated with USAID, Email: nir.ghanashyam@gmail.com 


\section{Introduction}

\subsection{Overview of Social Security in Nepal}

The history of social securitylaw can be tracked in the "English Poor Laws" in 1601 which was the first codification andtells about the liability for the social well-being of English citizens.Germany adopted social security in 1889. Similarly, America in 1935 adopted social insurance for the welfare of its citizens.

The Universal Declaration of Human Rights in Article 22 clearly indicated that everyone has a right to social security and to realise it through national and international cooperation (United Nations, 2014). Furthermore, Article 25 of the same declaration imparts that everyone has the right to live a standard of life for his health or his family and also has the right of social security in the event of unemployment, sickness, widowhood, old age, disability and in difficult conditions beyond his control.

Social security as "the protection that a society provides to individuals and households to ensure access to health care and to guarantee income security, particularly in cases of old age, unemployment, sickness, invalidity, work injury, maternity or loss of a breadwinner" (ILO, 2010). Merriam Webster Online Dictionary (2014) indicated Social security as a program or provision from the government for economic security or social welfare of a person or a family who are unable to work because they are old, disabled, or unemployed.

In the recent days along with different and drastic changes in the political situation, Nepal is also creeping ahead to ensure the peopleespecially the vulnerable groups benefitted through the program of socially protection. The first step towards it was initiated in 1994 by the first Nepal communist party UML led government. The communist government made an announcement of monthly one hundred rupees allowance for the senior citizens who fall in the seventy- fiveyears and above group.

The government had allocated 3\% of the total budget in the fiscal year 2014/2015 and the total number of beneficiaries in the same year were about $8 \%$ of the total population in the country( GoN, 2014). Certainly, it may be a challenge for a country like Nepal to allocate amount in social security whose economy largely depends on foreign aid. The number of beneficiaries may also differ in future due to demographic changes because the birth rate is decliningand the elderly population is increasing . The Crude Birth Rate is 22.4 per 1000 ( NDHS, 2016) and life expectancy at birth is increasing (66.6 years) in Nepal according to the census data of Nepal 2011 ( CBS, 2014, vol 1).

The first step towards distributing social security allowance to the elderly people ( 70 years and above) was initiated in 1994 by the Nepal communist party UML led government. But since then, the after formed governments are also adding some more provisions and amenities to make the beneficiaries' lives easier through social protection. At present social security allowance with different rates is being distributed throughout the country in the form of cash to different categories people.

$74 \sim$ Nepalese Journal of Insurance and Social Security 
The Constitution of Nepal (2015) clearly states the provision of social security in the section of Fundamental rights and duties. Similarly, the Civil Servant Act (1993), the Children's Act 1992, Senior Citizens Act 2006, the Social Welfare Act 1992, the Labour Law, the Trade Union Act are some existing laws and regulations that address the social security of people in Nepal.

Ministry of Federal Affairs and Local Development Department, Government of Nepal of Vital Registration in its websiteas well as the Social Security Program Operation Procedure, 2012, specifies that at present social security allowance with different rates is being distributed throughout the country in the form of cash to different categories people such as: senior citizen, senior Dalit citizens, senior citizens of Karnali, widow, single women, children of Karnali and Dalit, fully disable, severely affected disable, endangered indigenous nationalities (MOFALD, 2017). The Dalit caste people are the most disadvantaged groups and in the ancient Hindu caste system they fall under the lowest hierarchy and were also considered as untouchable. Similarly, Karnali is the most backward, remote and excluded zone among the 14 zones in Nepal in terms of development and people in the Karnali region are in miserable condition ${ }^{2}$.Government started to distribute social security allowances to beneficiaries via branchless banking in three districts namely,Surkhet, Banke and Baglung as a new way in distributing social security allownaces since 2016.Still the branchless banking is limited in three districts.

\subsection{Procedure of Distributing Social Security Allowance}

First a person should be registered in the Village Development Comittee (VDC) or Municipality office as a permanent residence. If any person migrates from different parts of a country then he/she should bring a migration certificate from the previous VDC or Municipality and should have a citizenship certificate. Then only a person's vital event will be recorded or updated. Besides this, citizens should update any incidents happen in the family like birth, death, migration, marriage and divorce.

Second, the VDCs and Municipalities should also keep their record updated on a regular basis. They should remove the dead and out-migrated people and enter the newborn, newly married and in-migrated people. Still, the registration system is not refreshed and the staffs of the local bodies are using a large paper work which can be shorten through introducing the computers.

The social security allowance has helped a lot to the poor of each category beneficiaries. Dalit children pay school fee, widow used for buying food. The Assessment conducted by Government of Nepal, National Planning Commission on Social Security Allowances Program in Nepal revealed the fact that the beneficiaries spent their allowances in meeting both personal and household expenses. They spent on food, tea and snacks, clothes, festival celebration and transportation.

2 http://docr.gov.np/Home/SocialSecurity). 
The Assessment of Social Security Allowance program conducted by National Planning Commission of Nepal in 2012 found that most of the beneficiaries in the survey told the allowance was insufficient to cover their personal and household expenditure (NPC, 2012). Some of the family members misuse their allowances and do not give cash in the hands of the targeted people. Some people are deprived if they do not have documents such as: citizenship certificate, birth certificate and they should apply in their VDCs demanding the benefits.

The main objective of the paper is to examining the social security system of Nepal that has been introduce by the government of Nepal as a social protection tool. The study aims to explore the different forms of social security benefits, it's impacts and effects of branchless banking system in distributing social security allowances. It also discusses the challenges of the social security programs.The rest of the paper is organized as follows. The next section of the study is related with review of literature,third chapter discusses the methodlogyfllowed by result and discussion and lastly concludes based on the findings.

\section{Review of Literature}

\subsection{Review of Existing Regulation and Acts}

The Constitution of Nepal (2015) provisioned social security to its citizen under the section of Fundamental rights and duties. Article 41 provisioned rights for senior citizens, Article 42 specified the right to social justice, Article 43 mentioned right to social security. Similarly,there is the provision of making policy in order to protect the single women, orphans, children, disabled, incapacitated and people who are on the verge of extinction. The Civil Servant Act (1993) has some provisions to support the government employees during the period of retirement in different forms. For instance: provident fund, pension, and discount on health services. Likewise, free maternal care in government hospitals and some financial support for delivery women is also a form of social protection. However, the support is not sufficient to the people having lower economic status.

The basis for the distribution of social security allowances discussed above is the record of vital events registered with the local government authorities mainly: Village Development Committee (VDC) and Municipality offices. In the absence of the record, the beneficiaries will be deprived of such social security allowances. According to Birth, Death and Other Personal Events (Registration) Act, 1976, all events including birth, death, migration, divorce and marriage should be registered in the VDC and Municipality within 35 days where a citizen is residing permanently (MoFALD, 2013) ${ }^{3}$.

The Children's Act 1992 of Nepal has made provision that the government of Nepal should make arrangement for the health of pregnant mothers and mothers who

3 Now VDCs are changed to Rural Municipality.

$76 \sim$ Nepalese Journal of Insurance and Social Security 
recently delivered a child. Similarly, Senior Citizens Act 2006 has stated that it will be a responsibility of the state to provide medical services in concessions for the senior citizens. The Labour Actstates that if a worker is physically wounded, hurt seriously or dies in course of office work, then the family of a worker should be given compensation.

Furthermore, the Social Welfare Act, 1992 imparts that the Government of Nepal could operate a special program to serve interest and provide welfare to the child, old aged people and helpless. Likewise the Civil Service Act, 1993 has made a provision that every government employee is entitled to a monthly pension if he has been in the government service for more than twenty years. The Labour Law, Trade Union Act, Civil Servant Act, Children Act, Senior Citizen Act, the Social Welfare Act has made some provisions regarding to social protection of citizens. There is no effective mechanism to examine whether the laws are implemented or not. Notwithstanding, the laws relating to social security are in practice in and the laws become effective only when citizens of a country are aware and active.

\subsection{Emperical Review}

There has been a large extension of the social security programs throughout the developing countries in recent times. The role of social security is different and very important in developing countries than in developed countries. In the developing countries, social protection program has a strong focus in reducing poverty and supporting the poorest families. Similarly, in the developing countries social security is a key component of development policy and is expected to increase productive capacity through investing in human and physical effects. On the other hand, in the developed countries it is considered only to protect poor people from the worst effects of deprivation. In other words, income maintence or protecting living standards is considered as social protection in the developed countries. (Barrientos, 2010).

The aim of social protection is to reduce vulnerability and to manage the economic risks of household, individual and community (Johanna et al, 2009). Khanal (2012) in his report argued that Nepal in some extent has provided basic social protection to the people and there are policies and legal provisions for the social protection of general people. However, the programs are not sufficient and the employees in the government sector are more benefitted than in private sectors.

Social Protection helps an individual to get health care; it also gives income security when a person is old, sick, old and unemployed. It provides protection to a household, when a breadwinner is dead. As indicated by International Labour Organization (n.d.) in their report facts on Social Security that one in five people has social security in the world and the condition of social security is also not good in South Asia and Sub-Saharan Africa. Only 5 to 10 percentage of the working population gets social protection in the region. However, it is an important tool for the improvement of a society (ILO, 2010). 
Gillion (1994) pointed out that countries are restructuring and expanding their social security system according to the changes in political and economic conditions. The writer further pointed out that the social security should be extended to informal sectors, the government should give high priority by expanding public expenditures on social security programs and the willingness of upper income groups should be increased to support social security schemes.

A report " Social security: Issues, challenges and prospects" presented on International Labor Conference 89th Session published by the International Labor Office, Geneva argued that it is a challenging job to address the issue of social security because more than half of the people are excluded from any forms of social security. The statistics of the reportalso pointed that social security should also be able to respond to new demographic challenges for example: ageing and changing family structure, with implications of financing in the future (ILO, 2001).

In a case study on the use of smart cards to deliver government benefits in Andhra Pradesh, India the writer argues that, the smart card payment system has made the beneficiaries easier and also has empowered the female beneficiaries. Furthermore, it has also become effective to reduce fraud ( Johnson, 2011).

Roth (2013) argued that branchless banking is a strategy for delivering financial services to the clients in the absence of physical bank branches. In the branchless banking, customers do not directly deal with the bank. Instead, customers deal with retail agents, mobile network operator or prepaid card issuer. In this banking, customers could also exchange cash, for value or consumer goods. Similarly, Lyman et. al (2006) further said that the retail agents used Point of Sale (POS) machine to read the card to know the balance of customer and also perform some basic banking functions.

In the developing countries four broad types of institutions such as: the state, private market, civil society and the family provide mainly two types of social security: social assistance and social insurance. Social assistance is in cash or kind financed by the state such as: safety needs for poor people in need as a form of child and family support (ISS, 2008 \& PRB, 2009).

Sharma and Arora (2011)stated that in India promotional and protective measures are the two forms of social protection. Promotional social protection measures relied more on social assistance and protective measures mainly available to formal workers. Promotional measures include food and nutrition programs, housing programs for rural areas, self employment programs and wage employment programs.

\section{Methodology}

The paper is based on secondary sources to examine the social security program of Nepal. Secondary data has been obtained from the official websites of Department of 
Vital Registration, Government of Nepal. Three years data of beneficiaries (FY 2012/13 -2014/15) and four years data of rate of Social security allowance (FY 2012/13 -2016/17) have been used to analyse the social security program. Descriptive tools like growth, trend, percentage have been applied to analyse the data.

\section{Result and Discussion}

\subsection{Types of Social Security Programs}

Nepal the Government provides social security basd on age, sex, ethnicity and geographical location of citizens. Ministry of Local Development classifies social security in three categories viz. Social assistance, Social Insurance, Social Safety Net as the three different provisions of Social Security (MOLD, 2010). These are :

\subsubsection{Social Assistance}

a) Monthly allowances in a form of cash to senior citizens, widow, single women, disable, dalitchildren and people of endangered races. B) Health care: Maternity care, free treatment for all disease to the senior citizens having age 70 and above, and heart treatment to children below age of 14. c) Education: Provide uniform to school goers girls to enourage to enroll in school.

\subsection{2 .Social Insurance}

Provident fund, Civil service pension, Unemployment insurance, Foreign employment insurance.

\subsubsection{Social Safety Net}

Scholarship and free education for Dalit and endangered indigenous nationalities students, Food program and social security allowances for each family member of endangered indigenous nationalities, Financial assistance for inter-caste marriage.

\subsection{Distributionof Social Security Allowances by Branchless Banking}

Throughout 77 districts social security allowance for seniorcitizens, widow, single women Dalit children, disabled, and endangered indigenous nationalities was distributed cash through the local government. Cash disbursement system has some weakness that sometimes the cash goes to the family members and sometimes to the wrong persons. It has been realized that the cash payment system is cumbersome and unsecured. To overcome the weakness, payment is made through banks. Since banks are not available in every village, the cash was distributed through the evidence of signature or fingerprint of beneficiaries.

In order to overcome the problems, the government of Nepal took an intiative of branchless banking for the distribution of social security allowances to the beneficiaries. 
The government initiated branchless banking in three districts namely: Surkhet, Banke and Baglung with the assistance of the World Bank. Branchless banking is a process of distributing cash to the beneficiaries in villages by the local agents of a commercial bank in 2014.

The process seems to be little long at first, however, it was convenient to the beneficiaries. The local agent first verified the beneficiaries' personal information such as: name, date of birth, address, citizenship number with the VDC or Municipality record. After verification of the recepants, agent takes a photograph, and biometric of the concerned people and hand over cash at the first stage. Through this, it seems that there is less chance of manipulating the benefits of the beneficiaries by their family members.

Similarly, in the branchless banking, the beneficiaries will also be provided a smart card, which contains a chip where the personal detail of a concerned person is enclosed. The branchless banking is easier, faster and convenient. Additionally, the beneficiaries would have their bank account open where they could deposit their amount and also could use banking services. However, it is difficult to become the branchless banking successful until the registration of vital event record is completed and updated. If the vital event record is updated then the branchless banking program would be successful.

\subsection{Mode of Payments of Benefits}

The social security allowance is distributed throughtout the country three times a year by the local government entities such as Rural municipality or Municipality office. The beneficiary should renew their identity card annualy. With out the identity card no one is eligible to take the allowance and citizenship certificate is necessary to make their social security identity card. If any eligible person does not have citizenship certificate then he/ she won't be benefitted.

Furthermore, the beneficiary should go the place allocated by the local government body to take social security allowTance. The allowance will not be delivered to the houses of beneficiares. In the places where local government distribute social security allowance, there the government authority will deposit the amount in bank account of beneficiary from where the beneficiary could collect cash.

Although the social security program has helped the vulnerable and disadvantaged groups and also have contributed for the social welfare in some extent but still there are some hurdles and obstacles to get access to social security program. First, in order to get access to social securtity citizenship certificate is must. Still some backward and underprivileged people don't have citizenship certificate. Second, some do not have idea when and where the social security allowance will be distributed. So, throughout the districts all over the country the allowance should directly be deposited in the bank account of a beneficiary. However, all the beneficiaries donot have their bank account. Federal system has Federal government, 7 provincial and 753 local government are 
formed. Social security allowances is distributed through the banking system in 137 municipalities and 285 rural municipalities and remaining bodies still have not used the banking system as the banking services is not reached there ${ }^{4}$.

Third, children of dalit community are getting child protection grant but children other than dalit community who are poor and underpreviledged are not entitle to get the support. Some people argue that the children of poor families should also be benefitted by the children protection grant.

\subsection{The Trend of the Per Unit Support}

At present social security allowances is divided in ten different categories. The monthly allowances rate for FY 2015/16 for Senior citizens aged 70 years is Rs. 1000, senior Dalit citizens 60 years and above is Rs.1000, all senior citizens 60 years and above residing in Karnali zone is Rs.1000. Likewise, Single women and widow is Rs.1000, severly affected disable is Rs. 600 and fully disable is Rs.2000. Accordingly, children ( under the age of five years) of dalit caste groups and the children of Karnali zone get Rs 400 per month as child protection grant. Likewise, all the senior citizen above the years of 70 get Rs 1000 monthly as senior citizen treatment expense. The rate of Social security allowance for different citizens, community, locality and status over four fiscal years 2012/13 to 2016/17 has been presented in Table 1.

Table 1. Trend of Social security allowance rate FY 2012/13 -2016/17

\begin{tabular}{lccccc}
\hline & \multicolumn{3}{c}{ Monthly Allowance ( NRs.) } & Growth* \\
\cline { 2 - 5 } \multicolumn{1}{c}{ Beneficiaries } & $\mathbf{2 0 1 2 / 1 3}$ & $\mathbf{2 0 1 4 / 1 5}$ & $\mathbf{2 0 1 5 / 1 6}$ & $\mathbf{2 0 1 6 / 1 7}$ & (\%) \\
\hline $\begin{array}{l}\text { Senior citizens (Others, Dalit } \\
\text { and Karnali) }\end{array}$ & 500 & 500 & 1000 & 1000 & 100 \\
$\begin{array}{l}\text { Single/widow } \\
\text { Fully disable }\end{array}$ & 500 & 500 & 1000 & 1000 & 100 \\
$\begin{array}{l}\text { Severly affected disable } \\
\text { Endangered Indigenous/ }\end{array}$ & 1000 & 1000 & 2000 & 2000 & 100 \\
$\begin{array}{l}\text { Nationalities } \\
\text { Children ( Karnali and Dalit) }\end{array}$ & 200 & 300 & 600 & 600 & 100 \\
$\begin{array}{l}\text { Treatment for Senior citizens } \\
\text { (70 years and above) }\end{array}$ & 2000 & 1000 & 2000 & 2000 & 100 \\
\hline
\end{tabular}

Source: http://www.docr.gov.np/Home/SocialSecurity

${ }^{*}$ Growth in 2015/16 over 2012/14

N/A: Not applicable

4 http://www.docr.gov.np/, 2017 
Table 2 exhibits that during the study period, all allowances except treatment for senior citizens (70 years and above) increased equally i.e. by 100 percent. In FY 2015/16, rate of allowance was lowest for children (Karnali and Dalit) i.e. NRs. 400 and highest rate to fully disabled, Endangered Indigenous / Nationalities i.e. NRs. 2000 per month.

Since, the last three fiscal years, it is seen that the government is more concerned towards the health of the senior citizens 70 years and above. In the year 2014/15, the government provided Rs. 2000 as a one year medical expense to the senior citizens 70 years ago. One year after, the government made a provison to provide Rs. 500 monthly to the target groups. Interestingly, the government again upgraded the allowance rate and made a provisonto providemontlyRs. 1000 as medical expense to the same age group. Finally, endangered indigenous nationalities receive Rs 2000 per month as social security allowance from the government (MoFALD, 2017).

\subsection{Trend of Beneficiaries}

There were only nine different categories of beneficiaries receiving social security allowances, however the types of beneficiaries have reached ten now by adding the treatment of senior citizens. A new initiative from the fiscal year 2015/2016 the government added a provision of monthly Rs 500 as medical treatment expense for the senior citizens 70 years age and above. However, at present, as mentioned in the website of Department of vital registration, it is known that the medical treatment expense of senior citizen has become doubled and is Rs. 1000 per month ${ }^{5}$. The trend of beneficiaries over the last three years (2012/13, 2013/14 and 2014/15) is exhibited Table 2.

Table 2: Trend of Beneficiaries FY 2012/13 -2014/15

(Figure in '000)

\begin{tabular}{lcccccc}
\hline Beneficiaries & $\mathbf{2 0 1 2 / 1 3}$ & $\mathbf{2 0 1 3 / 1 4}$ & $\mathbf{2 0 1 4 / 1 5}$ & $\begin{array}{c}\text { Growth* } \\
\text { (\%) }\end{array}$ & $\begin{array}{c}\text { Trend } \\
\text { (\%) }\end{array}$ \\
\hline $\begin{array}{l}\text { 1. Senior citizens all ( Dalits, } \\
\text { Karnali and others) }\end{array}$ & 859 & 923 & 952 & 11 & I & 44 \\
$\begin{array}{l}\text { 2. Single/widow } \\
\text { 3. Disable }\end{array}$ & 722 & 655 & 647 & -10 & D & 30 \\
$\quad \begin{array}{l}\text { Fully and severly affected) } \\
\text { 4. Endangered ethnic group }\end{array}$ & 29 & 32 & 56 & 95 & I & 3 \\
5. Children ( Dalit and Karnali) & 550 & 19 & 22 & 18 & I & 1 \\
$\quad$ Total & $\mathbf{2 , 1 7 8}$ & $\mathbf{2 , 1 6 6}$ & $\mathbf{2 , 1 8 5}$ & $\mathbf{0 . 2 9}$ & & 100 \\
\hline
\end{tabular}

Source: Social Security Program Annual report 2014/2015, Department of vital registration, Ministry of Federal Affairs and Local Development, Kathmandu, Nepal

*Growth in 2015 over 2013, I: Inceraseing, D: Decreasing

5 http://docr.gov.np/Dashboard

$82 \sim$ Nepalese Journal of Insurance and Social Security 
From the above table it is seen the number of other groups is in increasing trend while Single/widow and Children (Dalit and Karnali) have been found in decreasing trend. Out of five clusters, the number of elder citizens is highest (44\%) followed by single widow (30\%) and children of Dalit and Karnali zone (23\%). Disable ( Fully and severly affected) and Endangered ethnic group are only 4 percent of total beneficiaries in 2015/16. The growth of the total beneficiaries is less than 1 percent during three year period but number of disabled increased by 95\% while widow / single women decreased by 10 percent in three years.

Throughout the last three fiscal years, the largest number of beneficiaries were senior citizens followed by Single women/widow and children. Senior citizens all means male or female citizens above 70 years including Dalit and Karnali senior citizens. The Dalits(traditionally untouchable in the Hindu caste system) and Karnali people also falls on the most disadvantaged group . Social Security program operation procedure, 2012 says if a woman is a divorcee or unmarried and has crossed 60 years of age then only she is eligible to get social security allowance.

The reasons behind the increasing in number of senior citizens improving in health conditions and average age. Likewise, due to the positive change in the norms of the traditional society towards re-marry might be one of the reasons of fall down the number of single/widow over the three fiscal years. Furthermore, it could be argued that the decrease in total fertility rate, increase use of contraceptives and migration of young people to gulf countries might be the reasons for decreasing number of children receiving benefits over the last three fiscal years.

\section{Conclusion}

Mainly there are three types of social security allowance payments models in Nepal such as: cash distribution in the hand of beneficiaries, payment through banking system and branchless banking. Branchless banking seems to be more convenient to the people of remote areas however, the system is in practice only in three districts. In addition to this, mobile banking could also be an alternative way to provide social protection benefits like in some African countries. Sending vouchers and coupons in the mobile phones of beneficiaries will help them to purchase consumer goods from the retailers.

Ten different categories people (senior citizens, senior Dalits, widow, single women, endangered indigenous nationalities, Dalit children, Karnali zone children, severe affected disable, fully disable, Karnali zone senior citizens) are receiving allowances as social security benefits. The amount differs slightly according to the types of beneficiaries. Fully disable and endangered indigenous nationalities receives more than all the beneficiaries and Dalit children get less.

The study concludes that during the study period, all allowances except treatment for senior citizens (70 years and above) increased by 100 percent. The rate of allowances 
was lowest for children ( Karnali and Dalit) i.e. NRs. 400 and highest rate for fully disabled, Endangered Indigenous / Nationalities. Since, the last three fiscal years, it is seen that the government is more concerned towards the health of the senior citizens 70 years and above. The number of beneficiaries viz. senior citizens all (Dalits, Karnali and others), disable (Fully and severly affected), Endangered ethnic group is in increasing trend while Single/widow and Children (Dalit and Karnali) have been found in decreasing trend. Out of five clusters, the number of elder citizens is highest followed by single widow and children of Dalit and Karnali zone. Disable (Fully and severly affected) and Endangered ethnic group are only 4 percent of total beneficiaries in 2015/16. The growth of the total beneficiaries is less than 1 percent during three year period but number of disabled increased by $95 \%$ while widow / single women decreased by 10 percent in three years. Throughout the last three fiscal years, the largest number of beneficiaries were senior citizens followed by Single women/widow and children. Senior citizens all means male or female citizens above 70 years including Dalit and Karnali senior citizens. The Dalits(traditionally untouchable in the Hindu caste system) and Karnali people also falls on the most disadvantaged group . Social Security program operation procedure, 2012 says if a woman is a divorcee or unmarried and has crossed 60 years of age then only she is eligible to get social security allowance.

The social protection program has helped a lot to the needy and economically insecure groups to fulfil their basic needs in some extent and the newly started Branchless Banking (BLB) will help the people living in remote areas get benefits in their own hands if the records in local government are maintained and updated on a regular basis. But, in future it may be a challenging job for the government if it does not become self dependent in accumulating the money by its own internal resources. 


\section{References}

Barrientos, A. (2010). Social Protection and Poverty - United Nations Research Institute for Social Development. Retrieved from https://www.abdn.ac.uk/...international development/.../Barrientos-pp.pd

Gillion, C. (1994). Social Security and Protection in the developing world.Retrieved fromwww.bls.gov/mlr/1994/09/art4full.pdf

Government of Nepal Department of Vital registration.( 2017). Samajik SurakshyaBhatta Dar. Retrieved on November 9, 2017, from http://docr.gov.np/Home/SocialSecurity

Government of Nepal Ministry of Finance. (2014). Budget Speech 2014-2015.Retrieved from http://mof.gov.np/en/content/mof-link-pages-3.html

Government of Nepal National Planning Commission Secretariat. (2014). Population Monograph of Nepal Volume 1 (Population dynamics) Kathmandu: Central Bureau of Statistics

ILO (2010). Labour and Social Trends in Nepal 2010. Kathamndu.

International Labour Office Geneva. (2001). Social security: Issues, challenges and prospects Sixth item on the agenda. in International Labour Conference 89th Session 2001. Report VI. Switzerland. Retrieved from www.ilo.org/public/ english/standards/relm/ilc/ilc89/pdf/rep-vi.pdf

International Labour Organization. (2010). Facts on Social Security. Retrieved from www.ilo.org/wcmsp5/groups/public/---.../wcms_067588.pdf

ISS (2008). Social Security in Africa. Development Issues Volume 10/ Number 2/ November 2008. Retrieved from http://www.iss.nl/fileadmin/ASSETS/iss/Documents/ DevISSues/DevISSues_Volume_10_number_2_November_2008_01.pdf

Johanna, A., Koettl, J. \& Wheeler,R.S. (2009). Definitions, Good Practices, and Global Estimates on the Status of Social Protection for International Migrants. Retreived from siteresources. worldbank.org/SOCIALPROTECTION/Resources/SP...DP/ 0909.pdf

Johnson, D. (2011). SSRN Electronic Library. Case Study on the Use of Smartcards to Deliver Government Benefits in Andhra Pradesh, India. Social science research network. Retreived from http://papers.ssrn.com/sol3/papers.cfm? abstract_id=1886014

Khanal, D.R. (2012). Social Security / Social Protection in Nepal :Situation Analysis Series. Retrieved from www.ilo.org/wcmsp5/groups/public/--.../wcms_216490.pdf

Lyman, T. R., Ivatury, G., \& Staschen S. (2006). Focus Note Use of agents in branchless banking for the poor: rewards, risks, and regulation.Retrieved from www.cgap. org/.../CGAP-Focus-Notes-Use-of-Agents-in-Branchless-Bank

Merriam Webster Online. (2014). AnEncyclopaedia of Britannica Company. Retrieved from www.merriam-webster.com/dictionary/social\%20security 